\title{
Cytochrome P450 3A4, 3A5, and 2C8 expression in breast, prostate, lung, endometrial, and ovarian tumors: relevance for resistance to taxanes
}

\author{
Maarten van Eijk ${ }^{1}$ (D) $\cdot$ René J. Boosman $^{1} \cdot$ Alfred H. Schinkel ${ }^{2} \cdot$ Alwin D. R. Huitema $^{1,3} \cdot$ Jos H. Beijnen $^{1,2,4}$
}

Received: 6 June 2019 / Accepted: 4 July 2019 / Published online: 15 July 2019

(c) The Author(s) 2019

\begin{abstract}
Enzymes of the cytochrome P450 (CYP) subfamily 3A and 2C play a major role in the metabolism of taxane anticancer agents. While their function in hepatic metabolism of taxanes is well established, expression of these enzymes in solid tumors may play a role in the in situ metabolism of drugs as well, potentially affecting the intrinsic taxane susceptibility of these tumors. This article reviews the available literature on intratumoral expression of docetaxel- and paclitaxel-metabolizing enzymes in mammary, prostate, lung, endometrial, and ovarian tumors. Furthermore, the clinical implications of the intratumoral expression of these enzymes are reviewed and the potential of concomitant treatment with protease inhibitors (PIs) as a method to inhibit CYP3A4-mediated metabolism is discussed.
\end{abstract}

Keywords CYP $\cdot$ Paclitaxel $\cdot$ Docetaxel $\cdot$ Ritonavir $\cdot$ Intratumoral

\section{Introduction}

Breast, prostate, and lung cancer were among the top five most diagnosed cancers worldwide in 2018, while endometrial and ovarian cancer were the most common and deadly gynecologic malignancies in Europe [1]. Despite the emergence of new targeted therapies such as immunotherapy, hormonal therapies, tyrosine kinase, and poly (ADP-ribose) polymerase (PARP) inhibitors, the taxanes, docetaxel and

Maarten van Eijk and René J. Boosman have contributed equally to this work.

\section{Maarten van Eijk}

maa.v.eijk@nki.nl

1 Department of Pharmacy and Pharmacology, The Netherlands Cancer Institute, Plesmanlaan 121, 1066 CX Amsterdam, The Netherlands

2 Division of Pharmacology, The Netherlands Cancer Institute, Plesmanlaan 121, 1066 CX Amsterdam, The Netherlands

3 Department of Clinical Pharmacy, University Medical Center Utrecht, Utrecht University, Heidelberglaan 100, 3584CX Utrecht, The Netherlands

4 Science Faculty, Utrecht Institute for Pharmaceutical Sciences (UIPS), Division of Pharmacoepidemiology and Clinical Pharmacology, Utrecht University, P.O. Box 80082, 3508 TB Utrecht, The Netherlands paclitaxel, are still important drugs used in the treatment of these malignancies both as single agents and as part of combination regimens [2-4]. This applies especially in malignancies with fewer treatment options available, such as triple negative breast cancer (TNBC) and metastatic castrationresistant prostate cancer (mCRPC) [5-7]. Moreover, a significant increase in survival has been observed in patients with metastatic and non-metastatic hormone naïve prostate cancer treated with docetaxel in addition to androgen-deprivation therapy (ADT) in the CHAARTED and STAMPEDE trials $[8,9]$.

The taxanes (see Fig. 1) bind to the tubulin $\beta$ subunit, where they stabilize the microtubules by precluding depolymerization. Thereby, cell arrest in the mitotic G2/M phase is induced, leading to cell death [10]. Although paclitaxel and docetaxel come from a similar class of chemotherapeutic agents, their pharmacological characteristics exhibit several differences. Compared to paclitaxel, docetaxel has a longer half-life, higher cytotoxicity, a lower schedule dependency, a different adverse effect profile, longer retention time, and higher in vivo accumulation in tumors [11, 12]. This has led to the more frequent use of docetaxel compared to paclitaxel [13]. Unfortunately, patients treated with docetaxel or paclitaxel will often develop resistance [14-18]. Interestingly, despite the similar structural characteristics of the two drugs, a lack of cross-resistance has been observed. For instance, 
Fig. 1 Chemical structures of the taxanes: a docetaxel and $\mathbf{b}$ paclitaxel

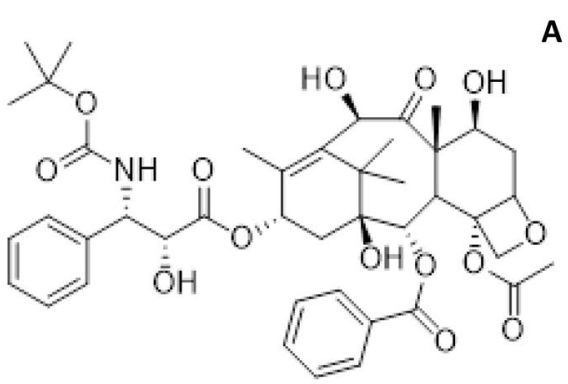

docetaxel has shown activity in a number of paclitaxelrefractory solid tumors [19-21].

Various mechanisms by which resistance to taxanebased chemotherapy can arise have been proposed. These mechanisms can broadly be classified into the following: (1) pre-target events resulting in reduced intracellular drug concentrations, (2) alterations of the drug-target interaction, or (3) factors influencing the cellular response to damage of the cytoskeleton [22]. Pre-target events could, for example, involve upregulation of the ATP-binding cassette $(\mathrm{ABC})$ drug efflux transporters such as P-glycoprotein (P-gp, ABCB1) or multidrug resistance protein (MRP1, ABCC1) and breast cancer resistance protein (BCRP, ABCG2) [23]. Furthermore, hepatic clearance through metabolizing enzymes from the Cytochrome P450 (CYP) superfamily can contribute to decreased plasma exposure. Both paclitaxel and docetaxel are mainly metabolized by CYP3A4. In addition, docetaxel is metabolized by CYP3A5 and paclitaxel by CYP2C8 [24-26].

CYP enzymes are also expressed in a variety of extrahepatic tissues. CYP3A, for example, is markedly expressed in the tissue of the digestive tract [27]. Similarly, it is known that various malignant tissues express CYP enzymes [28]. A variety of studies showed expression of CYP3A4 protein in breast, colorectal, esophageal tumors, and Ewing's sarcoma [29-33]. This expression of CYP enzymes in tumors may limit the intracellular concentrations of docetaxel and paclitaxel, which may cause pre-target resistance. The metabolites of both taxanes show very little if any cytotoxic activity. It has previously been described that the major metabolite of paclitaxel in humans, $6 \alpha$-hydroxypaclitaxel, does not induce growth inhibition in tumor cell lines [34]. Likewise, the metabolites of docetaxel show little-to-no antitumor activity [35]. The intratumoral expression of CYP enzymes could, therefore, limit efficacy or even contribute to the development of resistance to taxane therapy. This review will elaborate on the possible role of the CYP enzyme system in tumors of the breast, prostate, lung, ovaries, and endometrium in relation to the clinical pharmacology of docetaxel and paclitaxel. To this end, the expression of CYP enzymes in tumor tissue of different malignancies will be discussed, and possibilities for attenuation of CYP enzymes in tumors will be considered. To our knowledge, Oyama et al. were the first to review the intratumoral expression of CYP enzymes in 2004 [28]. In this review, we provide updated data on CYP3A4, CYP3A5, and CYP2C8 expression and review the impact of the intratumoral expression on taxane-based therapy.

\section{Drug-metabolizing CYP enzymes}

CYP enzymes are found predominantly in the liver and intestines and serve as a clearance mechanism by catalyzing the degradation of exogenous and endogenous substances. Approximately 60 human CYP genes are known, consisting of 18 gene families and 43 subfamilies [36]. CYP enzymes have a broad spectrum of functionalities in relation to cancer. On one hand, these enzymes may protect against carcinogens and even play a role in the activation of anticancer agents. For example, cyclophosphamide, an alkylating prodrug used as immune suppressor and chemotherapeutic for a range of tumors, is metabolized by CYP2A6, CYP2B6, CYP3A4, CYP3A5, CYP2C9, CYP2C18, and CYP2C19 to its active metabolites 4-hydroxy-cyclophosphamide and aldophosphamide [37]. On the other hand, CYP enzymes may play a role in the activation of carcinogens and the metabolism of anticancer drugs. For example, CYP1B1 is overexpressed in many tumor types in comparison to normal tissue and is known for its ability to activate a variety of carcinogens such as polycyclic aromatic hydrocarbons (PAH), heterocyclic amines, aromatic amines, and nitropolycyclic hydrocarbons. Moreover, many anticancer agents are metabolized by the CYP enzyme system into their inactive form [38-40]. One of the most abundantly expressed CYP enzymes is CYP3A4 which is responsible for the degradation of more than $60 \%$ of all marketed drugs [41]. The regulation of its expression has been investigated in a number of studies but has not been fully elucidated. The human pregnane $\mathrm{X}$ receptor or steroid xenobiotic receptor (SXR) is the most frequently studied receptor for the control of the CYP3A4 expression [42-45]. Activation of this receptor occurs after binding with CYP inducers, such as rifampicin but also in response to endogenous steroids such as estradiol $[46,47]$. Binding of the 
ligand to the receptor results in the dimerization of the SXR with the 9-cis-retinoid $\mathrm{X}$ receptor $(\mathrm{RXR} \alpha)$. This heterodimer subsequently binds to its response element on the CYP genes resulting in the transcriptional activation of CYP enzymes [48]. In addition, SXR can enhance drug efflux through the induction of P-gp [49]. It is known that steroid-dependent neoplasms such as breast and endometrial cancer express higher levels of SXR in neoplastic tissues than normal tissues [50, 51]. Paclitaxel, through SXR, markedly induces expression of CYP3A4 and CYP2C8 and P-gp, thereby preventing its own uptake and increasing its own metabolism and excretion when given in a weekly dosing schedule [49, 52, 53]. Conversely, docetaxel does not appear to enhance the activity of CYP3A4, although it does activate the transcriptional activation of SXR and CYP3A4 mRNA in human hepatocytes. However, this effect is very weak in comparison to that of paclitaxel $[52,53]$. If one of the above-mentioned mechanisms would similarly be present in tumor tissue, this could contribute to the development of resistance or unresponsiveness to chemotherapy in these cells.

\section{Expression of CYP3A4, CYP3A5, and CYP2C8 in tumors}

The expression of drug-metabolizing CYP enzymes in human tumors and other extrahepatic tissues has been a subject of investigation for several years [54]. Due to the metabolism or activation of many anticancer drugs by CYP enzymes, it is of particular interest to investigate whether CYP enzymes are also expressed in tumor tissue $[40,55]$. CYP expression in tumor and non-tumor tissues of the breast, colon, and lung has been thoroughly studied. However, tumor tissues such as the endometrium and prostate remain poorly investigated [28]. Methods often used to study the presence of CYP enzymes in tissues include immunohistochemistry (IHC) or western blot $[56,57]$. In addition, the presence of mRNA can be measured using reverse transcription polymerase chain reaction (RT-PCR) or Northern Blotting [58, 59]. Studies investigating the presence of CYP3A4/5 and CYP2C in extrahepatic tissues and tumors are summarized in Table 1.

\section{Breast cancer}

CYP enzymes are responsible for the phase I metabolism of estrogen and, therefore, have a prominent role in the pathogenesis of breast cancer. In extrahepatic tissues, CYP1B1 is responsible for the conversion of $17 \beta$-estradiol $\left(\mathrm{E}_{2}\right)$ into 4-hydroxyestradiol which may act as a carcinogen, while CYP1A1 and CYP3A4, on the other hand, metabolize $\mathrm{E}_{2}$ into its non-carcinogenic 2-hydroxy metabolite [60, 61]. This extrahepatic expression of enzymes may also have implications for treatment with taxanes. Studies using RTPCR to detect CYP3A4 mRNA have produced variable results with some studies indeed finding relevant CYP3A4 expression [62, 63], and some others find no expression of CYP3A at all [64, 65]. Other experiments using IHC or western blot to detect CYP3A protein expression also produced contrasting results [63, 66-68]. When comparing expression levels in malignant versus healthy tissue, results are similarly ambiguous with some studies finding a lower CYP3A4 expression in malignant tissues compared to adjacent morphologically normal tissue [56], and other studies suggesting increased expression of CYP3A4 in tumors [29, 69]. In one of the larger trials investigating CYP expression in mammary tumors, Haas and colleagues analyzed tissue from 393 breast cancer patients using IHC. Their analysis showed expression in $25 \%$ of mammary tumor samples screened for CYP3A4/5. Moreover, this CYP3A4/5 expression showed a significant association with a positive nodal status in patients $(P=0.018)$ [70]. In 2010, Murray and colleagues [32] also found an association between CYP3A4 expression and survival. Although the difference was marginal, patients with tumors that showed a low/ negative CYP3A4 immunoreactivity had a mean survival of 79 months (95\% confidence interval (CI) 77, 81), while patients with tumors that showed moderate/strong CYP3A4 immunoreactivity had a mean survival period of 86 months (95\% CI 79, 93) [32]. Some studies have investigated the mRNA and protein expression of enzymes of the CYP2C subfamily in breast cancer tumors with similar contradictory results $[62,63,65,67,68,71,72]$. Schmidt and colleagues, in addition to detecting CYP3A4 and CYP2C9 in breast cancer microsomes, also investigated the ability of these microsomes to metabolize ifosfamide. Using LC/MS, a minimal in vitro ifosfamide $\mathrm{N}$-dechloroethylation $(0.12 \pm 0.07 \mathrm{pmol}$ $\mathrm{min}^{-1} \mathrm{mg}_{\text {protein }}^{-1}$ ) could be detected in all four measured breast cancer microsomes. In comparison, previous investigation studies in liver samples from female patients had shown activities of $132 \pm 57 \mathrm{pmol} \mathrm{min}^{-1} \mathrm{mg}_{\text {protein }}^{-1}$ for ifosfamide $\mathrm{N}$-dechloroethylation $[71,73]$. Although very minimal, this demonstrates that the mechanism of CYP3A4-mediated ifosfamide metabolism is present in breast cancer microsomes.

Despite the large variability in reported expression frequencies, some larger studies suggest that the CYP3A4 protein is present somewhere between 20 and $55 \%$ of breast cancer tissues. For CYP2C enzymes, there also appears to be some expression in mammary tissue, whereas, for CYP3A5, this evidence is very limited. Although, in the majority of studies, the functionality of the enzyme remains to be elucidated, the fundamental conditions for CYP mediated metabolism appear to be present in a subpopulation of breast cancers which may have implications for taxane chemotherapy. 
Table 1 Overview of literature studies reporting the expression of CYP3A and CYP2C protein or mRNA from patient samples

\begin{tabular}{|c|c|c|c|c|c|c|c|c|c|}
\hline \multirow[t]{3}{*}{ Study } & \multirow[t]{3}{*}{ References } & \multicolumn{4}{|l|}{ CYP3A } & \multicolumn{4}{|l|}{ CYP2C } \\
\hline & & \multicolumn{2}{|l|}{ Protein } & \multicolumn{2}{|l|}{ mRNA } & \multicolumn{2}{|l|}{ Protein } & \multicolumn{2}{|l|}{ mRNA } \\
\hline & & Tumor $(n)$ & Healthy $(n)$ & Tumor $(n)$ & Healthy $(n)$ & Tumor $(n)$ & Healthy $(n)$ & Tumor $(n)$ & Healthy $(n)$ \\
\hline \multicolumn{10}{|l|}{ Breast cancer } \\
\hline Albin et al. (1993) & {$[68]$} & $0 \%(12)$ & $0 \%(12)$ & - & - & $0 \%(12)$ & $0 \%(12)$ & - & - \\
\hline $\begin{array}{l}\text { Hellmold et al. } \\
\text { (1998) }\end{array}$ & {$[63]$} & - & $0 \%(15)$ & $75 \%(4)$ & $73 \%(15)$ & - & $0 \%(14)^{c}$ & $100 \%$ & $100 \%(15)$ \\
\hline Murray et al. (1993) & {$[66]$} & $22 \%(54)^{\mathrm{a}}$ & - & - & - & - & - & - & - \\
\hline Huang et al. (1996) & {$[62]$} & - & - & $15 \%(13)$ & $\begin{array}{l}73 \%(11)^{\mathrm{a}} \\
82 \%(11)^{\mathrm{b}}\end{array}$ & - & - & $100 \%(13)$ & $100 \%(11)$ \\
\hline Yokose et al. (1999) & {$[67]$} & $0 \%(6)$ & - & - & - & $33 \%(6)$ & - & - & - \\
\hline Iscan et al. (2001) & {$[64]$} & - & - & $\begin{array}{l}0 \%(8)^{\mathrm{a}} \\
0 \%(4)^{\mathrm{b}}\end{array}$ & $\begin{array}{l}0 \%(8)^{\mathrm{a}} \\
0 \%(4)^{\mathrm{b}}\end{array}$ & - & - & $83 \%(6)$ & $83 \%(6)$ \\
\hline $\begin{array}{l}\text { Miyoshi et al. } \\
\text { (2002) }\end{array}$ & [101] & $37 \%(38)^{\mathrm{a}, \mathrm{d}}$ & - & - & - & - & - & - & - \\
\hline $\begin{array}{l}\text { El-Rayes et al. } \\
\text { (2003) }\end{array}$ & {$[56]$} & $+(29)$ & $+(29)$ & - & - & - & - & - & - \\
\hline $\begin{array}{l}\text { Kapucuoglu et al. } \\
\text { (2003) }\end{array}$ & [29] & $100 \%(25)^{\mathrm{a}}$ & $68 \%(25)^{\mathrm{a}}$ & - & - & - & - & - & - \\
\hline $\begin{array}{l}\text { Knüpfer et al. } \\
\text { (2004) }\end{array}$ & {$[72]$} & - & - & - & - & & - & $100 \%(10)^{\mathrm{c}}$ & - \\
\hline $\begin{array}{l}\text { Schmidt et al. } \\
\text { (2004) }\end{array}$ & [71] & $\begin{array}{l}100 \%(11)^{\mathrm{a}} \\
0 \%(10)^{\mathrm{b}}\end{array}$ & - & - & - & & - & - & - \\
\hline $\begin{array}{l}\text { Miyoshi et al. } \\
\text { (2005) }\end{array}$ & [102] & $52 \%(31)^{\mathrm{a}}$ & - & - & - & - & - & - & - \\
\hline Haas et al. (2006) & {$[70]$} & $25 \%(393)^{a, b}$ & - & - & - & - & - & - & - \\
\hline $\begin{array}{l}\text { Vaclavikova et al. } \\
\text { (2007) }\end{array}$ & {$[65]$} & - & - & $\operatorname{BLQ}(40)^{\mathrm{a}}$ & $\operatorname{BLQ}(40)^{\mathrm{a}}$ & - & - & & \\
\hline Murray et al. (2010) & {$[32]$} & $\begin{array}{l}52 \%(170)^{\mathrm{a}, \mathrm{d}, \mathrm{e}} \\
19 \%(170)^{\mathrm{b}, \mathrm{d}, \mathrm{e}}\end{array}$ & - & - & - & $30 \%(170)$ & - & - & - \\
\hline $\begin{array}{l}\text { Sakurai et al. } \\
\text { (2011) }\end{array}$ & [103] & $55 \%(42)^{\mathrm{a}}$ & - & - & - & - & - & - & - \\
\hline $\begin{array}{l}\text { Floriano-Sanchez } \\
\text { et al. (2014) }\end{array}$ & [69] & $+(48)^{*, a}$ & $+(48)^{\mathrm{a}}$ & - & - & - & - & - & - \\
\hline \multicolumn{10}{|l|}{ Prostate cancer } \\
\hline Murray et al. (1995) & [79] & $61 \%(51)$ & - & - & - & $25 \%(51)$ & - & - & - \\
\hline Yokose et al. (1999) & {$[67]$} & $0 \%(6)$ & - & - & - & $83 \%(6)$ & - & - & - \\
\hline $\begin{array}{l}\text { Finnström et al. } \\
\text { (2001) }\end{array}$ & {$[58]$} & - & - & $\begin{array}{l}11 \%(28)^{\mathrm{a}, \mathrm{f}} \\
86 \%(28)^{\mathrm{b}, \mathrm{f}}\end{array}$ & $\begin{array}{l}11 \%(28)^{\mathrm{a}, \mathrm{f}} \\
86 \%(28)^{\mathrm{b}, \mathrm{f}}\end{array}$ & - & - & - & - \\
\hline Koch et al. (2002) & {$[74]$} & - & - & - & $\begin{array}{l}0 \%(47)^{\mathrm{a}} \\
+(47)^{\mathrm{b}}\end{array}$ & - & - & - & - \\
\hline $\begin{array}{l}\text { Di Paolo et al. } \\
\text { (2005) }\end{array}$ & {$[80]$} & - & $\begin{array}{l}58 \%(24)^{\mathrm{a}} \\
54 \%(24)^{\mathrm{b}}\end{array}$ & - & - & - & - & - & - \\
\hline $\begin{array}{l}\text { Moilanen et al. } \\
\text { (2007) }\end{array}$ & {$[77]$} & - & $100 \%(6)^{b}$ & - & - & - & - & - & - \\
\hline Bièche et al. (2007) & {$[54]$} & - & - & - & $+(32)^{\mathrm{b}}$ & & & & \\
\hline $\begin{array}{l}\text { Leskelä et al. } \\
\text { (2007) }\end{array}$ & [76] & $0 \%(35)^{\mathrm{b}}$ & $100 \%(10)^{\mathrm{b}}$ & $0 \%(10)^{\mathrm{b}}$ & $+(10)^{\mathrm{b}}$ & - & - & - & - \\
\hline $\begin{array}{l}\text { Fujimura et al. } \\
\text { (2009) }\end{array}$ & {$[81]$} & $75 \%(107)^{\mathrm{a}}$ & $93 \%(88)^{\mathrm{a}}$ & - & - & - & - & - & - \\
\hline $\begin{array}{l}\text { Mitsiades et al. } \\
\text { (2012) }\end{array}$ & {$[75]$} & - & - & $+(146)^{\mathrm{a}, \mathrm{b}}$ & $+(29)^{* * a, b}$ & - & - & - & - \\
\hline
\end{tabular}


Table 1 (continued)

\begin{tabular}{|c|c|c|c|c|c|c|c|c|c|}
\hline \multirow[t]{3}{*}{ Study } & \multirow[t]{3}{*}{ References } & \multicolumn{4}{|l|}{ CYP3A } & \multicolumn{4}{|l|}{ CYP2C } \\
\hline & & \multicolumn{2}{|l|}{ Protein } & \multicolumn{2}{|l|}{ mRNA } & \multicolumn{2}{|l|}{ Protein } & \multicolumn{2}{|l|}{ mRNA } \\
\hline & & Tumor $(n)$ & Healthy $(n)$ & Tumor $(n)$ & Healthy $(n)$ & Tumor $(n)$ & Healthy $(n)$ & Tumor $(n)$ & Healthy $(n)$ \\
\hline \multicolumn{10}{|l|}{ NSCLC } \\
\hline $\begin{array}{l}\text { Nakajima et al. } \\
\text { (1994) }\end{array}$ & {$[85]$} & - & - & - & - & $+(27)$ & $+(11)$ & - & - \\
\hline Kivistö et al. (1995) & [86] & $25 \%(32)$ & $34 \%(32)$ & - & - & - & - & - & - \\
\hline Kivistö et al. (1996) & [87] & $100 \%(8)$ & $100 \%(8)$ & $\begin{array}{l}0 \%(8)^{\mathrm{a}} \\
50 \%(8)^{\mathrm{b}}\end{array}$ & $\begin{array}{l}0 \%(8)^{\mathrm{a}} \\
100 \%(8)^{\mathrm{b}}\end{array}$ & - & - & - & - \\
\hline Anttila et al. (1997) & {$[88]$} & - & $18,5 \%(27)^{\mathrm{a}}$ & - & $\begin{array}{l}13 \%(8)^{\mathrm{a}} \\
100 \%(8)^{\mathrm{b}}\end{array}$ & - & - & - & - \\
\hline Macé et al. (1998) & {$[84]$} & - & - & - & $\begin{array}{l}0 \%(14)^{\mathrm{a}} \\
93 \%(14)^{\mathrm{b}}\end{array}$ & - & - & - & $100 \%(14)$ \\
\hline Yokose et al. (1999) & {$[67]$} & $0 \%(18)$ & & & & $0 \%(18)$ & & & \\
\hline $\begin{array}{l}\text { Fujitaka et al. } \\
\text { (2001) }\end{array}$ & {$[90]$} & - & - & $+(10)^{\mathrm{a}}$ & $+(10)^{\mathrm{a}}$ & - & - & $+(10)^{*}$ & $+(10)$ \\
\hline Bièche et al. (2007) & {$[54]$} & - & - & - & $+(6)^{\mathrm{b}}$ & - & - & - & - \\
\hline Qixing et al. (2017) & [89] & $\begin{array}{l}74 \%(87)^{* * *, a, d} \\
+(87)^{b, d}\end{array}$ & $\begin{array}{l}+(87)^{\mathrm{a}} \\
+(87)^{* * *, \mathrm{~b}}\end{array}$ & - & - & - & - & - & - \\
\hline \multicolumn{10}{|l|}{ Endometrial cancer } \\
\hline $\begin{array}{l}\text { Hukkanen et al. } \\
\text { (1998) }\end{array}$ & [94] & - & - & - & $\begin{array}{l}57 \%(7)^{\mathrm{a}} \\
43 \%(7)^{\mathrm{b}}\end{array}$ & - & - & - & - \\
\hline Yokose et al. (1999) & {$[67]$} & $0 \%(12)$ & & & & $0 \%(12)$ & & & \\
\hline Sarkar et al. (2003) & [95] & - & - & - & $57 \%(23)^{\mathrm{a}}$ & - & - & - & - \\
\hline $\begin{array}{l}\text { Masuyama et al. } \\
\text { (2003) }\end{array}$ & {$[50]$} & - & - & $+(20)^{\mathrm{a}}$ & - & - & - & - & - \\
\hline \multicolumn{10}{|l|}{ Ovarian cancer } \\
\hline Yokose et al. (1999) & {$[67]$} & $0 \%(12)$ & - & - & - & $0 \%(12)$ & - & - & - \\
\hline Klose et al. (1999) & {$[91]$} & - & - & - & - & - & - & - & $100 \%(1)$ \\
\hline $\begin{array}{l}\text { Downie et al. } \\
\text { (2005) }\end{array}$ & {$[98]$} & $\begin{array}{l}91 \%(99) / \\
80 \%(22)^{\mathrm{a}, \mathrm{g}} \\
66 \%(99) / \\
55 \%(22)^{\mathrm{b}, \mathrm{g}}\end{array}$ & $\begin{array}{l}64 \%(13)^{\mathrm{a}} \\
55 \%(13)^{\mathrm{b}}\end{array}$ & - & - & $\begin{array}{l}17 \%(99) / \\
10 \%(22)^{\mathrm{g}}\end{array}$ & $36 \%(13)$ & - & - \\
\hline Bièche et al. (2007) & {$[54]$} & - & - & - & $+(15)^{b}$ & - & - & - & $+(15)$ \\
\hline DeLoia et al. (2008) & [97] & - & - & $\begin{array}{l}9 \%(47)^{\mathrm{a}} \\
89 \%(47)^{\mathrm{b}}\end{array}$ & - & - & - & $69 \%(48)^{\mathrm{c}}$ & - \\
\hline
\end{tabular}

The percentages shown indicate the number of samples in which CYP enzymes could be detected, with in parentheses the total amount of samples/patients analyzed. (+) indicates CYP enzymes were expressed, but the exact number of positive samples was not described or presented as immunoreactivity score. (-) indicates not measured. $P$ values indicate higher proportion, immunoreactivity score, or expression level compared to respective tumor/non-tumor sample, $* P<0.05$, $* * P<0.01$, $* * * P<0.001$

$B L Q$ below limit of quantification

${ }^{\mathrm{a} O n l y ~ C Y P 3 A 4}$

${ }^{\mathrm{b}}$ Only CYP3A5

${ }^{\mathrm{c}}$ Only CYP2C8

${ }^{\mathrm{d}}$ Percentage indicates a fraction of tumors with moderate/high expression

${ }^{\mathrm{e}}$ Original data from publication received from the authors

${ }^{\mathrm{f}}$ No distinction between tumor and non-tumor tissue

${ }^{\mathrm{g}}$ Percentages for primary ovarian cancer and peritoneal metastases, respectively

\section{Prostate cancer}

Interestingly, several studies which measured CYP3A mRNA in both normal prostate and cancerous tissue seem to suggest that CYP3A5 is the most abundant CYP in these tissues [54, 58, 74-77]. Even though about $80 \%$ of Caucasians are CYP3A5 deficient [78]. While studies investigating CYP3A protein expression in tumor samples have mainly 
found relatively high expression of both CYP3A4 and CYP3A5 both in tumor and non-tumor tissue [79-81]. Furthermore, enzymes of the CYP2C family were also detected in tumor samples in some studies [67, 79]. In 2009, Fujimura and colleagues detected CYP3A4 in healthy prostate and prostate cancer tissue and found that prostate cancer cells had a lower CYP3A4 immunoreactivity score (sum of the proportion of positively stained cells and staining intensity; $3.6 \pm 2.6)$ compared to the benign epithelium $(4.5 \pm 2.1$; $P<0.0001)$. Moreover, this lower immunoreactivity score showed a significant inverse correlation with a higher Gleason score and a poorer prognosis in patients [81]. This result was supported by the finding of a decreased expression of CYP3A4 and CYP3A5 in CRPC cells compared to benign prostate tissue [75]. Physiologically, this could be explained by a reduced conversion of androgens, such as testosterone into the inactive $6 \beta$-hydroxytestosterone $(6 \beta-\mathrm{OH}-\mathrm{T})$ metabolite, leading to increased androgen-dependent proliferation. A hypothesis is supported by the association between CYP3A4 and CYP3A5 polymorphisms and haplotypes and prostate cancer risk and aggressiveness $[82,83]$. In conclusion, heterogeneous CYP3A4, CYP3A5, and CYP2C8 expression in neoplasms of the prostate is observed, possibly contributing to variable treatment response to taxanes, even though the expression may be decreased in malignant tissue in comparison to healthy tissue.

\section{Non-small cell lung cancer (NSCLC)}

RT-PCR analyses have shown that CYP3A4 and CYP3A5 are present in healthy and malignant lung tissue [54, 84, 85]. Yet, results of IHC analyses are less clear, although the CYP3A4 protein is expressed in about $20 \%$ of the observed tissue samples [86-88]. A more recent study showed that CYP3A4 expression was significantly higher in tumor tissue when compared with normal lung tissue [89]. These results, obtained from an online data set on CYP3A4 and CYP3A5 expression, did not contain data whether the patients received prior chemotherapy or not. Therefore, the study also featured an IHC analysis of 92 patients, who were included prior to any chemotherapy treatment. In this subset, a significant higher CYP3A4 expression was observed in comparison with the adjacent healthy tissue. In addition, CYP3A4 expression was significantly correlated with advanced TNM stages $(P=0.013)$ and poor histological differentiation $(P=0.017)$, while CYP3A5 was only significantly associated with histological differentiation. Moreover, an association between high-CYP3A4 or lowCYP3A5 expression and poor survival could be observed [89]. CYP2C gene-expression levels were found to be significantly increased in lung cancer tissue compared to healthy lung tissue [90]. In the study by Klose et al, CYP2C8 mRNA expression was found to be highly variable, although some older studies were able to detect CYP2C8 protein or mRNA [84, 85, 91]. In conclusion, taxane-metabolizing enzymes appear to be present in both healthy and malignant lung tissue, and upregulation of these enzymes may be observed in malignant tissue.

\section{Endometrial cancer}

Estrogen itself is an important contributor to the growth and development of endometrial tumors. Contrary to the effects of progesterone, estrogen stimulates the endometrium to proliferate. A misbalance in favor of estrogen may, therefore, contribute to the early stages of endometrial cancer formation [92]. The extrahepatic metabolism of estrogen by CYP1B1, 1A1, and CYP3A4 is described above. As in breast cancer, these enzymes may also be present in endometrial tumors and play a role in local estrogen metabolism. The presence of CYP3A4 and CYP3A5 enzymes in endometrial cells seems variable with some studies finding no CYP3A4 and CYP3A5 mRNA, but high expression of CYP3A7 mRNA in the endometrium and placenta [93]. In contrast to this finding, other studies found expression of CYP2C, CYP3A4, CYP3A5, and CYP3A7 mRNA among other CYP enzymes in normal endometrium tissue [94, 95]. Another study found that CYP3A4 and CYP3A7 mRNA expression was low in normal endometrium, but was significantly upregulated in endometrial cancer tissues [50]. Together, this suggests some expression on an mRNA level of taxane-metabolizing enzymes of the CYP3A subfamily in healthy endometrium and endometrial cancer, although the small body of evidence does not allow for any strong conclusions.

\section{Ovarian cancer}

As in breast and endometrial cancer, it is thought that estrogen plays a similar role in tumor initiation and promotion in ovarian cancer [96]. CYP enzymes may, therefore, also play a similar role in ovarian tumors. The presence of CYP2C8 and CYP3A5 mRNA has been reported in ovarian tissue [54, 91]. However, mRNA in both studies was collected from the whole gland tissue, whereas ovarian tumors are mainly of epithelial origin [97]. Downie et al. found that CYP3A5, among other CYP enzymes, had a significantly greater intensity of IHC staining $(P<0.001)$ in primary ovarian cancer tissue compared with normal ovary [98]. A later study investigated the presence of taxane-metabolizing enzymes in ovarian cancer and found that CYP3A4 is expressed at very low levels in ovarian cancer, while CYP3A5 and CYP2C8 were expressed in the majority of ovarian tumors, regardless of histologic type, stage, or grade [97]. As in endometrium, evidence regarding the expression of taxane-metabolizing CYP enzymes in the ovaries and in ovarian cancer is limited. 
Although the studies available seem to suggest a relatively high expression compared to other tissues, especially for CYP3A5.

\section{Taxanes and CYP3A expression in tumor cells}

The hepatic induction of CYP3A enzymes by paclitaxel and to a lesser degree by docetaxel prompts questions whether a similar mechanism could have an effect on the expression of CYP3A enzymes in tumors [52]. This mechanism may be of clinical relevance during the application of taxane chemotherapy as it may impact treatment outcome [49, 52, 53]. In vitro studies have shown that human prostate cancer (DU145) and breast cancer (MCF-7) cells lines indeed express a higher amount of CYP3A4 protein in response to treatment with docetaxel $[99,100]$. In addition, Ikezoe and colleagues found a 2.0-fold increase in CYP3A4 expression in DU-145 xenografts in BNX nude mice after treatment with docetaxel [99]. Fujitaka and colleagues observed an increase in CYP3A4 mRNA expression in peripheral mononuclear cells from patients with previously untreated lung cancer after treatment with docetaxel. For CYP2C8, no such increase could be observed [90]. Similarly, DeLoia et al. investigated gene expression of CYP2C8, CYP3A4, CYP3A5, and $\mathrm{ABCB} 1$ in epithelial ovarian tumors, and exposed these tumor cells to docetaxel and paclitaxel ex vivo. There was no apparent correlation between any single gene expressed and taxane disposition, although a strong correlation between the ratio of CYP3A5:ABCB1 and the clearance of docetaxel was observed [97].

The presence of CYPs in tumors can similarly be linked to clinical outcomes of docetaxel treatment. Miyoshi et al. found that CYP3A4 expression in tumors, measured by mRNA and IHC, correlates with clinical outcomes in breast cancer patients treated with docetaxel. Patients with low CYP3A4 mRNA levels $(n=14)$ exhibited a significantly higher response rate to docetaxel treatment than those with high CYP3A4 mRNA levels ( $n=9,71 \%$ vs. $11 \%, P<0.01)$ [101]. In addition, patients with CYP3A4-negative tumors $(n=15)$, determined by IHC, showed a significantly higher response rate to docetaxel treatment than those with CYP3A4-positive tumors $(n=16,67 \%$ vs. $19 \%, P<0.01)$ [102]. Later, breast cancer tissue obtained from a larger trial in 42 patients who underwent docetaxel treatment as adjuvant chemotherapy after surgery was analyzed for CYP3A4 expression using IHC. The 19 patients with CYP3A4-negative tumors showed a significantly higher response rate to docetaxel treatment than the 23 patients with CYP3A4positive tumors $(63.2 \%$ vs. $26.1 \%, P<0.01)$. Moreover, a higher clinical benefit rate was observed in CYP3A4-negative tumors ( $73.7 \%$ vs. $26.1 \%, P<0.01)$ as well as a longer time to progression $(8.9 \pm 5.8$ months vs. $5.2 \pm 4.4$ months, $P<0.05)$. These results suggest that assessing CYP3A4 expression in breast cancer may be a relevant tool to predict the response of the tumor to docetaxel treatment [103]. In 16 patients with NSCLC receiving docetaxel or docetaxel and carboplatin for advanced disease, CYP3A4 gene expression in peripheral mononuclear cells was analyzed. After $24 \mathrm{~h}$, the CYP3A4 expression was significantly increased when compared to baseline. Treatment with carboplatin monotherapy did not cause any statistically significant difference in CYP3A4 expression. In the same study, 20 autopsy samples (10 NSCLC +10 control) from chemotherapy-naïve patients were analyzed on the levels of CYP3A4 gene expression. Although the variability in gene expression was high, there was no significant difference between healthy and cancerous tissue. In the case of CYP2C8, however, increased expression in tumor tissue could be observed [90].

Despite the small number of patients included in these studies, the evidence presented seems to indicate that an increase in intratumoral CYP3A4 expression can be observed after treatment with taxanes. Increased CYP3A4 expression could be inversely correlated to clinical response rates to these drugs. Together, this suggests that these CYP enzymes are part of a resistance mechanism in which the in situ metabolism of docetaxel is accelerated, thereby diminishing response to docetaxel-containing chemotherapy.

\section{Concomitant treatment with taxanes and HIV-protease inhibitors}

As a notorious group of CYP3A4 inhibitors, it is of great interest to know whether or not HIV-protease inhibitors (PIs) will have an effect on intratumoral CYP3A4 functionality. Ritonavir, developed as an HIV PI, is one of the most potent inhibitors of CYP3A4 known, although the precise mechanism of inhibition has yet to be clarified [104, 105]. Ritonavir is used in HIV therapy to boost the concentration of other drugs with a known CYP3A4-dependent metabolism [106]. Its effect on CYP3A4 is irreversible, and consequently, the reversal of inhibition is dependent on the degradation halflife of CYP3A4, which is thought to be about $29 \mathrm{~h}$. After cessation of ritonavir treatment, CYP3A4 expression returns to baseline after approximately 6 days $[107,108]$. Docetaxel is strongly metabolized by CYP3A4, and hence, it is hypothesized that concomitant treatment of docetaxel and ritonavir will increase the antitumor activity of docetaxel [99]. Pharmacokinetic parameters of docetaxel such as clearance and half-life are decreased and increased, respectively, when co-administered with ritonavir [109-111]. Several in vivo studies have shown the effect on the tumor response after coadministration with ritonavir [99, 112]. In one study with an immunocompetent, orthotopic Cyp $3 \mathrm{a}^{-/-}$mouse model, the 
effect of intravenous docetaxel and oral ritonavir on Cyp3a expressing $\mathrm{K} 14 \mathrm{cre}$; $\mathrm{Brca} 1^{\mathrm{F} / \mathrm{F}}$; $\mathrm{p} 53^{\mathrm{F} / \mathrm{F}}$ mammary tumors was studied [112]. The co-treatment led to a decrease in tumor volume greater than docetaxel treatment alone (70\% vs. $30 \%$ shrinkage of the initial tumor volume after 3 weeks of treatment). In addition, the median time in which the tumor reached the critical tumor size (approximately $1500 \mathrm{~mm}^{3}$ ) was significantly increased when docetaxel and ritonavir were given together $(65.6 \pm 8.6$ days vs. 53.6 \pm 1.5 days for docetaxel monotherapy). As expected, the plasma concentration of docetaxel did not show significant differences in the ritonavir co-administered group. However, the intratumoral docetaxel concentration was significantly higher after 9 days of treatment with docetaxel and ritonavir in comparison with docetaxel monotherapy. Furthermore, the docetaxel metabolite concentrations were lower in the combination treatment group compared to the group treated with single-agent docetaxel, suggesting that ritonavir specifically inhibited the intratumoral metabolism of docetaxel [112].

PIs do not only interfere with the metabolism of taxanes by direct inhibition of CYP3A4, but could also amplify their antitumor effects via additional mechanisms. Table 2 summarizes the proposed synergistic effect of the PIs to docetaxel treatment. Using western blot analysis, it was shown that ritonavir could potentiate the effect of docetaxel on the activation of caspase- 3 and the cleavage of PARP (which is cleaved as a late event during apoptosis). Ritonavir can inhibit the docetaxel-induced increase in CYP3A4 mRNA completely in the mouse androgen-dependent prostate cancer cells. In vivo docetaxel markedly decreased the growth rate and size of DU145 tumors in male BNX mice. Ritonavir alone showed no statistical significance either in growth or in weight of the tumors. Interestingly, the combination of the taxane and the PI showed an additional statistically significant decrease in both growth and tumor weights in comparison with the monotherapy of docetaxel. Histologically, a site composed of necrotic and fibrotic tissue was observed, but no cells of cancerous origin were detected. Moreover, the organs of the mice were not affected. In addition, ritonavir has shown to block the DNA-binding activity of $\mathrm{NF \kappa B}$ in the DU145 cells and in vivo [99].

In various types of cancer including prostate cancer, hyperactivity of the NFKB pathway has been observed
[113]. This hyperactivity often results in the development of resistance to several anticancer drugs such as paclitaxel and docetaxel [99, 112]. By decreasing the DNA-binding activity of $\mathrm{NF \kappa B}$, it is possible that ritonavir surpasses this resistance mechanism of docetaxel and will, therefore, increase the effectiveness of the docetaxel treatment. In the lung cancer cell line NCI-H460, a decrease in growth of 39 and $21 \%$ was observed when treated with single-agent nelfinavir and docetaxel, respectively. However, when the cell lines were incubated with nelfinavir prior to docetaxel, a growth inhibition of $51 \%$ was observed. Similar effects were observed in the NCI-H520 cell line, suggesting that the nelfinavir-induced inhibition of the Akt signaling results in more sensitivity to docetaxel treatment [114]. The activation of Akt pathway is described in the literature as being responsible for the development of resistance, and as a result, tumors are often overexpressing Akt in these cell populations [115]. Moreover, docetaxel resistance is tackled in some studies by inhibiting the Akt pathway and therefore resensitizing the tumor cells for docetaxel treatment $[116,117]$. Whether ritonavir acts the same way as nelfinavir on NSCLC cells is not studied in the earlier mentioned article. Yet, there are reports that ritonavir can block the Akt signaling in ovarian cancer and breast cancer and, thus, can re-sensitize the resistant tumor cells for docetaxel treatment [118, 119].

In summary, the co-treatment of docetaxel with ritonavir enhances the cytotoxic activity of docetaxel in the tumor and ritonavir could, therefore, potentiate the effect of docetaxel as a chemotherapeutic agent. Currently, the first Phase I and II trials using an oral formulation of docetaxel called ModraDoc006 co-administered with ritonavir are underway in mCRPC (NCT03136640) and metastatic breast cancer (NCT03890744). Earlier trials with this formulation in patients with various solid tumors have shown promising antitumor activity and highlight the potential of this innovative way of attenuating CYP activity to boost oral docetaxel bioavailability and to possibly improve clinical efficacy [120-122].

Table 2 Proposed synergistic effects of protease inhibitors (PI) to docetaxel treatment examined in in vitro studies

\begin{tabular}{llllll}
\hline Cell line & PI & Proposed effect & References \\
\hline NCI-H460 & Nelfinavir & Nelfinavir-induced inhibition of Akt signaling leading to more sensitivity to docetaxel & [114] & \\
NCI-H520 & & & [99] & [99] \\
DU145 cell line & Ritonavir & Increased effect of docetaxel on activation of caspase-3 and cleavage of PARP & [99] \\
DU145 cell line & Ritonavir & Reduced DNA-binding activity of NFKB, surpassing one resistance mechanism of docetaxel & \\
DU145 cell line & Ritonavir & Blocked the docetaxel-induced increase in CYP3A4 mRNA, decreasing the metabolism of docetaxel & [99]
\end{tabular}




\section{Discussion}

Although evidence remains slightly contradictory and many studies are limited by low sample sizes, there appears to be relevant expression of taxane-metabolizing enzymes CYP3A4, CYP3A5 and CYP2C8, among other CYP enzymes, in some malignant and non-malignant tissues of the breast, prostate, lung, endometrium, and ovaries $[29,32,56,58,62,63,66,67,69-72,76,77,79-81$, 84, 86-89, 94, 95, 97, 98, 101-103]. Individual studies in NSCLC, and breast and ovarian cancer show increased expression in malignant versus non-malignant tissue [69, 89, 98], whereas, in prostate cancer, this ratio may be decreased [76, 81]. What is important to note, however, is that mRNA expression does not necessarily correlate with protein expression, and that protein detection by IHC discloses no information on the functional status of an enzyme. CYP3A4 appears to be upregulated as a response to docetaxel in a preclinical setting [90,99]. Moreover, CYP3A4 expression can function as a predictor of the efficacy of docetaxel chemotherapy $[101,102]$.

Other than the synergistic mechanisms described above, PIs may contribute to inhibition of tumor proliferation through intrinsic antitumor effects [109]. Several mechanisms have been described by which these inhibitors are capable of reducing cancer growth [123]. For example, in breast cancer cells, ritonavir has been shown to inhibit heat shock protein 90 (Hsp90) and Akt, thereby inhibiting the growth of these cells [118]. In the androgen-independent prostate cancer cell lines, DU-145 and PC3, the HIV PIs saquinavir, ritonavir, and indinavir were effective in inhibiting the proliferation of these cells in a dosedependent manner. Ritonavir was most prone to inhibit the proliferation, showing a 50\% decrease in the growth of DU145 (half maximum inhibitory concentration (IC50) of $3 \times 10^{-6} \mathrm{~mol} / \mathrm{L}$ ) and PC-3 cells (IC50 of $8 \times 10^{-6} \mathrm{~mol} / \mathrm{L}$ ). However, the studied concentrations are approximately 1000-fold higher than the concentrations observed after standard dosage regimens of ritonavir in humans, raising the question whether the inhibition of proliferation can be observed in clinical practice $[99,124]$.

Although this review focusses specifically on PIs as a boosting strategy, the effect of other CYP3A4 inhibitors on the intratumoral concentrations of docetaxel may be an interesting topic for further study. One such example is cobicistat, specifically developed as a boosting agent, and an equally potent but more specific inhibitor of CYP3A4 than ritonavir, without inducing properties. Consequently, it might have fewer unwanted drug-drug interactions [125].

Considering the currently available information, in addition to hepatic CYP enzymes, intratumoral enzymes may play a role in the in situ metabolism of taxane chemotherapy and could, therefore, present an important factor influencing the outcomes of treatment. In the future, more systematic analysis of CYP expression in tumors may be a tool by which treatment response may be predicted or function as a criterion by which patients may be selected for treatment. In conclusion, the attenuation of CYP enzymes in tumors appears to be an interesting area of research through which the clinical benefit of anticancer agents may be potentiated.

Acknowledgements This research did not receive any specific grant from funding agencies in the public, commercial, or not-for-profit sectors.

\section{Compliance with ethical standards}

Conflict of interest Jos Beijnen is a (part-time) employee and shareholder of Modra Pharmaceuticals, and (partly) holds a patent on oral taxane formulations. The other authors declare that they have no conflict of interest.

Ethical approval This article does not contain any studies with human participants or animals performed by any of the authors.

Open Access This article is distributed under the terms of the Creative Commons Attribution 4.0 International License (http://creativeco mmons.org/licenses/by/4.0/), which permits unrestricted use, distribution, and reproduction in any medium, provided you give appropriate credit to the original author(s) and the source, provide a link to the Creative Commons license, and indicate if changes were made.

\section{References}

1. World Health Organization International Agency for Research on Cancer (IACR) (2018) GLOBOCAN 2018: IARC Global Cancer Observatory. http://gco.iarc.fr/today/home. Accessed 31 May 2019

2. Montero A, Fossella F, Hortobagyi G, Valero V (2005) Docetaxel for treatment of solid tumours: a systematic review of clinical data. Lancet Oncol 6:229-239. https://doi.org/10.1016/S1470 $-2045(05) 70094-2$

3. Crown J, O'Leary M (2000) The taxanes: an update. Lancet 355:1176-1178. https://doi.org/10.1016/S0140-6736(00)02074-2

4. Akram T, Maseelall P, Fanning J (2005) Carboplatin and paclitaxel for the treatment of advanced or recurrent endometrial cancer. Am J Obstet Gynecol 192:1365-1367. https://doi. org/10.1016/j.ajog.2004.12.032

5. Tannock IF, de Wit R, Berry WR et al (2004) Docetaxel plus prednisone or mitoxantrone plus prednisone for advanced prostate cancer. N Engl J Med 351:1502-1512. https://doi. org/10.1056/NEJMoa040720

6. Masoud V, Pagès G (2017) Targeted therapies in breast cancer: new challenges to fight against resistance. World J Clin Oncol 8:120. https://doi.org/10.5306/wjco.v8.i2.120

7. Serpa Neto A, Tobias-Machado M, Kaliks R et al (2011) Ten years of docetaxel-based therapies in prostate adenocarcinoma: a systematic review and meta-analysis of 2244 patients in 12 
randomized clinical trials. Clin Genitourin Cancer 9:115-123. https://doi.org/10.1016/j.clgc.2011.05.002

8. Sweeney CJ, Chen Y-H, Carducci M et al (2015) Chemohormonal therapy in metastatic hormone-sensitive prostate cancer. $\mathrm{N}$ Engl J Med 373:737-746. https://doi.org/10.1056/NEJMoa1503 747

9. James ND, Sydes MR, Clarke NW et al (2016) Addition of docetaxel, zoledronic acid, or both to first-line long-term hormone therapy in prostate cancer (STAMPEDE): survival results from an adaptive, multiarm, multistage, platform randomised controlled trial. Lancet 387:1163-1177. https://doi.org/10.1016/ S0140-6736(15)01037-5

10. Tulsyan S, Chaturvedi P, Singh AK et al (2014) Assessment of clinical outcomes in breast cancer patients treated with taxanes: multi-analytical approach. Gene. https://doi.org/10.1016/j. gene.2014.04.004

11. Gligorov J, Lotz JP (2004) Preclinical pharmacology of the taxanes: implications of the differences. Oncologist 9:3-8. https://doi.org/10.1634/theoncologist.9-suppl_2-3

12. Lyseng-Williamson KA, Fenton C (2005) Docetaxel: a review of its use in metastatic breast cancer. Drugs 65:2513-2531. https://doi.org/10.2165/00003495-200565170-00007

13. Cortes JE, Pazdur R (1995) Docetaxel. J Clin Oncol 13:26432655. https://doi.org/10.1200/JCO.1995.13.10.2643

14. Gan L, Wang J, Xu H, Yang X (2011) Resistance to docetaxelinduced apoptosis in prostate cancer cells by $\mathrm{p} 38 / \mathrm{p} 53 / \mathrm{p} 21$ signaling. Prostate 71:1158-1166. https://doi.org/10.1002/ pros. 21331

15. Patterson SG, Wei S, Chen $X$ et al (2006) Novel role of Stat 1 in the development of docetaxel resistance in prostate tumor cells. Oncogene 25:6113-6122. https://doi.org/10.1038/sj.onc.12096 32

16. Codony-Servat J, Marín-Aguilera M, Visa L et al (2013) Nuclear factor-kappa B and interleukin-6 related docetaxel resistance in castration-resistant prostate cancer. Prostate 73:512-521. https ://doi.org/10.1002/pros.22591

17. Brown I, Shalli K, McDonald SL et al (2004) Reduced expression of p27 is a novel mechanism of docetaxel resistance in breast cancer cells. Breast Cancer Res 6:R601-R607. https:// doi.org/10.1186/bcr918

18. Zhang X, Zhong S, Xu Y et al (2016) MicroRNA-3646 contributes to docetaxel resistance in human breast cancer cells by GSK-3 $\beta / \beta$-catenin signaling pathway. PLoS One. https://doi. org/10.1371/journal.pone.0153194

19. Valero V, Jones SE, Von Hoff DD et al (1998) A phase II study of docetaxel in patients with paclitaxel-resistant metastatic breast cancer. J Clin Oncol 16:3362-3368. https://doi.org/10.1200/ JCO.1998.16.10.3362

20. Verschraegen CF, Sittisomwong T, Kudelka AP et al (2000) Docetaxel for patients with paclitaxel-resistant mullerian carcinoma. J Clin Oncol 18:2733-2739. https://doi.org/10.1200/ JCO.2000.18.14.2733

21. Kondoh C, Takahari D, Shitara K et al (2012) Efficacy of docetaxel in patients with paclitaxel-resistant advanced gastric cancer. Gan To Kagaku Ryoho 39:1511-1515

22. Zunino F, Cassinelli G, Polizzi D, Perego P (1999) Molecular mechanisms of resistance to taxanes and therapeutic implications. Drug Resist Updat 2:351-357. https://doi.org/10.1054/ drup.1999.0108

23. Germano S, O’Driscoll L (2009) Breast cancer: understanding sensitivity and resistance to chemotherapy and targeted therapies to aid in personalised medicine. Curr Cancer Drug Targets 9:398-418. https://doi.org/10.2174/156800909788166529

24. Engels FK, Ten Tije AJ, Baker SD et al (2004) Effect of cytochrome P450 3A4 inhibition on the pharmacokinetics of docetaxel. Clin Pharmacol Ther 75:448-454. https://doi. org/10.1016/j.clpt.2004.01.001

25. Cresteil T, Monsarrat B, Dubois J et al (2002) Regioselective metabolism of taxoids by human CYP3A4 and 2C8: structureactivity relationship. Drug Metab Dispos 30:438-445. https:// doi.org/10.1124/dmd.30.4.438

26. Shou M, Martinet M, Korzekwa KR et al (1998) Role of human cytochrome P450 3A4 and 3A5 in the metabolism of Taxotere and its derivatives: enzyme specificity, interindividual distribution and metabolic contribution in human liver. Pharmacogenetics 8:391-401. https://doi.org/10.1097/00008571-19981 0000-00004

27. Thelen K, Dressman JB (2009) Cytochrome P450-mediated metabolism in the human gut wall. J Pharm Pharmacol 61:541558. https://doi.org/10.1211/jpp/61.05.0002

28. Oyama T, Kagawa N, Naoki Kunugita N et al (2004) Expression of cytochrome $\mathrm{P} 450$ in tumor tissues and its association with cancer development. Front Biosci 9:1967-1976. https://doi. org/10.2741/1378

29. Kapucuoglu N, Coban T, Raunio H et al (2003) Expression of CYP3A4 in human breast tumour and non-tumour tissues. Cancer Lett 202:17-23. https://doi.org/10.1016/j.canlet.2003.08.015

30. Martínez C, García-Martín E, Pizarro RM et al (2002) Expression of paclitaxel-inactivating CYP3A activity in human colorectal cancer: implications for drug therapy. Br J Cancer 87:681686. https://doi.org/10.1038/sj.bjc.6600494

31. Murray GI, Shaw D, Weaver RJ et al (1994) Cytochrome P450 expression in oesophageal cancer. Gut 35:599-603. https://doi. org/10.1136/gut.35.5.599

32. Murray GI, Patimalla S, Stewart KN et al (2010) Profiling the expression of cytochrome $\mathrm{P} 450$ in breast cancer. Histopathology 57:202-211. https://doi.org/10.1111/j.1365-2559.2010.03606.x

33. Zia H, Murray GI, Vyhlidal CA et al (2015) CYP3A isoforms in Ewing's sarcoma tumours: an immunohistochemical study with clinical correlation. Int J Exp Pathol 96:81-86. https://doi. org/10.1111/iep.12115

34. Sparreboom A, Huizing MT, Boesen JJB et al (1995) Isolation, purification, and biological activity of mono- and dihydroxylated paclitaxel metabolites from human feces. Cancer Chemother Pharmacol 36:299-304. https://doi.org/10.1007/BF00689047

35. Sparreboom A, Van Tellingen O, Scherrenburg EJ et al (1996) Isolation, purification and biological activity of major docetaxel metabolites from human feces. Drug Metab Dispos 24:655-658

36. Nelson DR (1998) Cytochrome P450 nomenclature. Methods Mol Biol 107:15-24. https://doi.org/10.1385/0-89603-519-0:15

37. De Jonge M, Huitema A, Rodenhuis S, Beijnen JH (2005) Clinical pharmacokinetics of cyclophosphamide. Clin Pharmacokinet 44:1135-1164

38. Bruno RD, Njar VCO (2007) Targeting cytochrome P450 enzymes: a new approach in anti-cancer drug development. Bioorg Med Chem 15:5047-5060. https://doi.org/10.1016/j. bmc.2007.05.046

39. Rendic S, Guengerich FP (2012) Contributions of human enzymes in carcinogen metabolism. Chem Res Toxicol 25:13161383. https://doi.org/10.1021/tx300132k

40. Zanger UM, Schwab M (2008) Cytochrome P450 enzymes in drug metabolism: regulation of gene expression, enzyme activities, and impact of genetic variation. Pharmacol Ther 138:103141. https://doi.org/10.1016/j.pharmthera.2012.12.007

41. Traunecker HCL, Stevens MCG, Kerr DJ, Ferry DR (1999) The acridone carboxamide GF120918 potently reverses P-glycoprotein-mediated resistance in human sarcoma MES-Dx 5 cells. $\mathrm{Br}$ J Cancer 81:942-951. https://doi.org/10.1038/sj.bjc.6690791

42. Bertilsson G, Heidrich J, Svensson K et al (1998) Identification of a human nuclear receptor defines a new signaling pathway for 
CYP3A induction. Proc Natl Acad Sci USA 95:12208-12213. https://doi.org/10.1073/pnas.95.21.12208

43. Blumberg B, Sabbagh W, Juguilon $\mathrm{H}$ et al (1998) SXR, a novel steroid and xenobiotic-sensing nuclear receptor. Genes Dev 12:3195-3205. https://doi.org/10.1101/gad.12.20.3195

44. Kliewer SA, Moore JT, Wade L et al (1998) An orphan nuclear receptor activated by pregnanes defines a novel steroid signaling pathway. Cell 92:73-82. https://doi.org/10.1016/S0092 -8674(00)80900-9

45. Lehmann JM, McKee DD, Watson MA et al (1998) The human orphan nuclear receptor PXR is activated by compounds that regulate CYP3A4 gene expression and cause drug interactions. J Clin Investig 102:1016-1023. https://doi.org/10.1172/JCI37 03

46. Banerjee M, Robbins D, Chen T (2013) Modulation of xenobiotic receptors by steroids. Molecules 18:7389-7406. https://doi. org/10.3390/molecules 18077389

47. Goodwin B, Hodgson E, Liddle C (1999) The orphan human pregnane $X$ receptor mediates the transcriptional activation of CYP3A4 by rifampicin through a distal enhancer module. Mol Pharmacol 56:1329-1339. https://doi.org/10.1124/mol.56.6.1329

48. Huss JM, Wang SI, Astrom A et al (1996) Dexamethasone responsiveness of a major glucocorticoid-inducible CYP3A gene is mediated by elements unrelated to a glucocorticoid receptor binding motif. Proc Natl Acad Sci USA 93:4666-4670. https:// doi.org/10.1073/pnas.93.10.4666

49. Synold T, Dussault I, Forman B (2001) The orphan nuclear receptor SXR coordinately regulates drug metabolism and efflux. Nat Med 7:1-7. https://doi.org/10.1038/87912

50. Masuyama H, Hiramatsu Y, Kodama JI, Kudo T (2003) Expression and potential roles of pregnane $\mathrm{X}$ receptor in endometrial cancer. J Clin Endocrinol Metab 88:4446-4454. https://doi. org/10.1210/jc.2003-030203

51. Miki Y, Suzuki T, Kitada K et al (2006) Expression of the steroid and xenobiotic receptor and its possible target gene, organic anion transporting polypeptide-A, in human breast carcinoma. Cancer Res 66:535-542. https://doi.org/10.1158/0008-5472. CAN-05-1070

52. Nallani SC, Goodwin B, Buckley AR et al (2004) Differences in the induction of cytochrome P450 3A4 by taxane anticancer drugs, docetaxel and paclitaxel, assessed employing primary human hepatocytes. Cancer Chemother Pharmacol 54:219-229. https://doi.org/10.1007/s00280-004-0799-9

53. Harmsen S, Meijerman I, Beijnen JH, Schellens JHM (2009) Nuclear receptor-mediated induction of cytochrome P450 3A4 by anticancer drugs: a key role for the pregnane $\mathrm{X}$ receptor. Cancer Chemother Pharmacol 64:35-43. https://doi.org/10.1007/s0028 0-008-0842-3

54. Bièche I, Narjoz C, Asselah T et al (2007) Reverse transcriptasePCR quantification of mRNA levels from cytochrome (CYP)1, CYP2 and CYP3 families in 22 different human tissues. Pharmacogenet Genomics 17:731-742. https://doi.org/10.1097/ FPC.0b013e32810f2e58

55. Patterson LH, Murray GI (2002) Tumour cytochrome P450 and drug activation. CurrPharmDes 8:1335-1347. https://doi. org/10.2174/1381612023394502

56. El-Rayes BF, Ali S, Heilbrun LK et al (2003) Cytochrome p450 and glutathione transferase expression in human breast cancer. Clin Cancer Res 9:1705-1709

57. Murray GI, Taylor MC, McFadyen MCE et al (1997) Tumorspecific expression of cytochrome P450 CYP1B1. Cancer Res 57:3026-3031. https://doi.org/10.1016/j.neuint.2010.10.017

58. Finnström N, Bjelfman C, Söderström TG et al (2001) Detection of cytochrome P450 mRNA transcripts in prostate samples by RT-PCR. Eur J Clin Investig 31:880-886. https://doi.org/10.104 6/j.1365-2362.2001.00893.x
59. Mclemore TL, Adelberg S, Liu MC et al (1990) Expression of CYP1A1 gene in patients with lung cancer: evidence for cigarette smoke-induced gene expression in normal lung tissue and for altered gene regulation in primary pulmonary carcinomas. J Natl Cancer Inst 82:1333-1339. https://doi.org/10.1093/ jnci/82.16.1333

60. Yager JD, Davidson NE (2006) Estrogen carcinogenesis in breast cancer. N Engl J Med 354:270-282. https://doi.org/10.1056/ NEJMra050776

61. Tsuchiya Y, Nakajima M, Yokoi T (2005) Cytochrome $\mathrm{P} 450$-mediated metabolism of estrogens and its regulation in human. Cancer Lett 227:115-124. https://doi.org/10.1016/j.canle t.2004.10.007

62. Huang Z, Fasco MJ, Figge HL et al (1996) Expression of cytochromes P450 in human breast tissue and tumors. Drug Metab Dispos 24:899-905

63. Hellmold H, Rylander T, Magnusson M et al (1998) Characterization of cytochrome P450 enzymes in human breast tissue from reduction mammaplasties. J Clin Endocrinol Metab 83:886-895. https://doi.org/10.1210/jcem.83.3.4647

64. Iscan M, Klaavuniemi T, Coban T et al (2001) The expression of cytochrome P450 enzymes in human breast tumours and normal breast tissue. Breast Cancer Res Treat 70:47-54. https://doi. org/10.1023/A:1012526406741

65. Vaclavikova R, Hubackova M, Stribrna-Sarmanova J et al (2007) RNA expression of cytochrome P450 in breast cancer patients. Anticancer Res 27:4443-4450

66. Murray GI, Weaver RJ, Paterson PJ et al (1993) Expression of xenobiotic metabolizing enzymes in breast cancer. J Pathol 169:347-353. https://doi.org/10.1002/path.1711690312

67. Yokose T, Doy M, Taniguchi T et al (1999) Immunohistochemical study of cytochrome P450 2C and 3A in human non-neoplastic and neoplastic tissues. Virchows Arch 434:401-411. https:// doi.org/10.1007/s004280050359

68. Albin N, Mathieu MC, Massaad L et al (1993) Main drug-metabolizing enzyme systems in human breast tumors and peritumoral tissues. Cancer Res 53:3541-3546

69. Floriano-Sanchez E, Rodriguez NC, Bandala C, CoballaseUrrutia E (2014) CYP3A4 expression in breast cancer and its association with risk factors in Mexican women. Asian Pac J Cancer Prev 15:3805-3809. https://doi.org/10.7314/APJCP 2014.15.8.3805

70. Haas S, Pierl C, Harth V et al (2006) Expression of xenobiotic and steroid hormone metabolizing enzymes in human breast carcinomas. Int J Cancer 119:1785-1791. https://doi.org/10.1002/ ijc. 21915

71. Schmidt R, Baumann F, Knüpfer H et al (2004) CYP3A4, CYP2C9 and CYP2B6 expression and ifosfamide turnover in breast cancer tissue microsomes. Br J Cancer 90:911-916. https ://doi.org/10.1038/sj.bjc.6601492

72. Knüpfer H, Schmidt R, Stanitz D et al (2004) CYP2C and IL-6 expression in breast cancer. Breast 13:28-34. https://doi. org/10.1016/j.breast.2003.07.002

73. Schmidt R, Baumann F, Hanschmann H et al (2001) Gender difference in ifosfamide metabolism by human liver microsomes. Eur J Drug Metab Pharmacokinet 26:193-200. https://doi. org/10.1007/BF03190396

74. Koch I, Weil R, Wolbold R et al (2002) Interindividual variability and tissue-specificity in the expression of cytochrome P450 3a mRNA. Drug Metab Dispos 30:1108-1114. https://doi. org/10.1124/dmd.30.10.1108

75. Mitsiades N, Sung CC, Schultz N et al (2012) Distinct patterns of dysregulated expression of enzymes involved in androgen synthesis and metabolism in metastatic prostate cancer tumors. Cancer Res 72:6142-6152. https://doi.org/10.1158/0008-5472. CAN-12-1335 
76. Leskelä S, Honrado E, Montero-Conde C et al (2007) Cytochrome P450 3A5 is highly expressed in normal prostate cells but absent in prostate cancer. Endocr Relat Cancer 14:645654. https://doi.org/10.1677/ERC-07-0078

77. Moilanen AM, Hakkola J, Vaarala MH et al (2007) Characterization of androgen-regulated expression of CYP3A5 in human prostate. Carcinogenesis 28:916-921. https://doi.org/10.1093/ carcin/bgl222

78. Blanco JG, Edick MJ, Hancock ML et al (2002) Genetic polymorphisms in CYP3A5, CYP3A4 and NQO1 in children who developed therapy-related myeloid malignancies. Pharmacogenetics 12:605-611. https://doi.org/10.1097/00008571-20021 1000-00004

79. Murray GI, Taylor VE, McKay JA et al (1995) The immunohistochemical localization of drug-metabolizing enzymes in prostate cancer. J Pathol 177:147-152. https://doi.org/10.1002/ path. 1711770208

80. Di Paolo OA, Teitel CH, Nowell S et al (2005) Expression of cytochromes $\mathrm{P} 450$ and glutathione S-transferases in human prostate, and the potential for activation of heterocyclic amine carcinogens via acetyl-CoA-, PAPS- and ATP-dependent pathways. Int J Cancer 117:8-13. https://doi.org/10.1002/ijc.21152

81. Fujimura T, Takahashi S, Urano T et al (2009) Expression of cytochrome P450 3A4 and its clinical significance in human prostate cancer. Urology 74:391-397. https://doi.org/10.1016/j. urology.2009.02.033

82. Loukola A, Chadha M, Penn SG et al (2004) Comprehensive evaluation of the association between prostate cancer and genotypes/haplotypes in CYP17A1, CYP3A4 and SRD5A2. Eur J Hum Genet 12:321-332. https://doi.org/10.1038/sj.ejhg.52011 01

83. Plummer SJ, Conti DV, Paris PL et al (2003) CYP3A4 and CYP3A5 genotypes, haplotypes, and risk of prostate cancer. Cancer Epidemiol Biomarkers Prev 12:928-932

84. Macé K, Bowman ED, Vautravers P et al (1998) Characterisation of xenobiotic-metabolising enzyme expression in human bronchial mucosa and peripheral lung tissues. Eur J Cancer 34:914-920. https://doi.org/10.1016/S0959-8049(98)00034-3

85. Nakajima T, Elovaara E, Gonzalez F et al (2005) Styrene metabolism by cDNA-expressed human hepatic and pulmonary cytochromes P450. Chem Res Toxicol 7:891-896. https://doi. org/10.1021/tx00042a026

86. Kivistö KT, Fritz P, Linder A et al (1995) Immunohistochemical localization of cytochrome P450 3A in human pulmonary carcinomas and normal bronchial tissue. Histochem Cell Biol 103:25-29

87. Kivistö KT, Griese EU, Fritz P et al (1996) Expression of cytochrome P 4503 A enzymes in human lung: a combined RTPCR and immunohistochemical analysis of normal tissue and lung tumours. Naunyn Schmiedebergs Arch Pharmacol 353:207212. https://doi.org/10.1007/BF00168759

88. Anttila S, Hukkanen J, Hakkola J et al (1997) Expression and localization of CYP3A4 and CYP3A5 in human lung. Am J Respir Cell Mol Biol 16:242-249. https://doi.org/10.1165/ajrcm b.16.3.9070608

89. Qixing M, Juqing X, Yajing W et al (2017) The expression levels of CYP3A4 and CYP3A5 serve as potential prognostic biomarkers in lung adenocarcinoma. Tumor Biol. https://doi. org/10.1177/1010428317698340

90. Fujitaka K, Oguri T, Isobe T et al (2001) Induction of cytochrome P450 3A4 by docetaxel in peripheral mononuclear cells and its expression in lung cancer. Cancer Chemother Pharmacol 48:4246. https://doi.org/10.1007/s002800100291

91. Klose TS, Blaisdell JA, Goldstein JA (1999) Gene structure of CYP2C8 and extrahepatic distribution of the human CYP2Cs.
J Biochem Mol Toxicol 13:289-295. https://doi.org/10.1002/ (SICI)1099-0461(1999)13:6\%3c289:AID-JBT1\%3e3.0.CO;2-N

92. Rodriguez AC, Blanchard Z, Maurer KA, Gertz J (2019) Estrogen signaling in endometrial cancer: a key oncogenic pathway with several open questions. Horm Cancer 10:51-63. https://doi. org/10.1007/s12672-019-0358-9

93. Schuetz JD, Kauma S, Guzelian PS (1993) Identification of the fetal liver cytochrome CYP3A7 in human endometrium and placenta. J Clin Investig 92:1018-1024. https://doi.org/10.1172/ JCI1 16607

94. Hukkanen J, Mäntylä M, Kangas L et al (1998) Expression of cytochrome $\mathrm{P} 450$ genes encoding enzymes active in the metabolism of tamoxifen in human uterine endometrium. Pharmacol Toxicol 82:93-97. https://doi.org/10.1111/j.1600-0773.1998. tb01404.x

95. Sarkar MA, Vadlamuri V, Ghosh S, Glover DD (2003) Expression and cyclic variability of CYP3A4 and CYP3A7 isoforms in human endometrium and cervix during the menstrual cycle. Drug Metab Dispos 31:1-6. https://doi.org/10.1124/dmd.31.1.1

96. Ho SM (2003) Estrogen, progesterone and epithelial ovarian cancer. Reprod Biol Endocrinol. https://doi. org/10.1186/1477-7827-1-73

97. DeLoia JA, Zamboni WC, Jones JM et al (2008) Expression and activity of taxane-metabolizing enzymes in ovarian tumors. Gynecol Oncol 108:355-360. https://doi.org/10.1016/j.ygyno 2007.10.029

98. Downie D, McFadyen MCE, Rooney PH et al (2005) Profiling cytochrome P450 expression in ovarian cancer: identification of prognostic markers. Clin Cancer Res 11:7369-7375. https://doi. org/10.1158/1078-0432.CCR-05-0466

99. Ikezoe T, Hisatake Y, Takeuchi T et al (2004) HIV-1 protease inhibitor, ritonavir: a potent inhibitor of CYP3A4, enhanced the anticancer effects of docetaxel in androgen-independent prostate cancer cells in vitro and in vivo. Cancer Res 64:7426-7431. https ://doi.org/10.1158/0008-5472.CAN-03-2677

100. Li W-J, Zhong S-L, Wu Y-J et al (2013) Systematic expression analysis of genes related to multidrug-resistance in isogenic docetaxel- and adriamycin-resistant breast cancer cell lines. Mol Biol Rep 40:6143-6150. https://doi.org/10.1007/s11033-013-2725-x

101. Miyoshi Y, Ando A, Takamura Y et al (2002) Prediction of response to docetaxel by CYP3A4 mRNA expression in breast cancer tissues. Int J Cancer 97:129-132. https://doi.org/10.1002/ ijc. 1568

102. Miyoshi Y, Taguchi T, Kim SJ et al (2005) Prediction of response to docetaxel by immunohistochemical analysis of CYP3A4 expression in human breast cancers. Breast Cancer 12:11-15. https://doi.org/10.2325/jbcs.12.11

103. Sakurai K, Enomoto K, Matsuo S et al (2011) CYP3A4 expression to predict treatment response to docetaxel for metastasis and recurrence of primary breast cancer. Surg Today 41:674-679. https://doi.org/10.1007/s00595-009-4328-7

104. Eagling VA, Back DJ, Barry MG (1997) Differential inhibition of cytochrome $\mathrm{P} 450$ isoforms by the protease inhibitors, ritonavir, saquinavir and indinavir. Br J Pharmacol 44:190-194. https://doi. org/10.1046/j.1365-2125.1997.00644

105. Sevrioukova IF, Poulos TL (2010) Structure and mechanism of the complex between cytochrome P4503A4 and ritonavir. Proc Natl Acad Sci 107:18422-18427. https://doi.org/10.1073/ pnas. 1010693107

106. Hull MW, Montaner JSG (2011) Ritonavir-boosted protease inhibitors in HIV therapy. 2:375-388. https://doi. org/10.3109/07853890.2011.572905

107. Ramsden D, Zhou J, Tweedie DJ (2015) Determination of a degradation constant for CYP3A4 by direct suppression of mRNA in a novel human hepatocyte model, HepatoPac. Drug Metab Dispos 43:1307-1315. https://doi.org/10.1124/dmd.115.065326 
108. Rock BM, Hengel SM, Rock DA et al (2014) Characterization of ritonavir-mediated inactivation of cytochrome P450 3A4. Mol Pharmacol 86:665-674. https://doi.org/10.1124/mol.114.094862

109. Yu H, Hendrikx JJMA, Rottenberg S et al (2016) Development of a tumour growth inhibition model to elucidate the effects of ritonavir on intratumoural metabolism and anti-tumour effect of docetaxel in a mouse model for hereditary breast cancer. AAPS J 18:362-371. https://doi.org/10.1208/s12248-015-9838-1

110. Rudek MA, Chang CY, Steadman K et al (2014) Combination antiretroviral therapy (cART) component ritonavir significantly alters docetaxel exposure. Cancer Chemother Pharmacol 73:729736. https://doi.org/10.1007/s00280-014-2399-7

111. Hendrikx JJMA, Lagas JS, Wagenaar E et al (2014) Oral coadministration of elacridar and ritonavir enhances plasma levels of oral paclitaxel and docetaxel without affecting relative brain accumulation. Br J Cancer 110:2669-2676. https://doi. org/10.1038/bjc.2014.222

112. Hendrikx JJMA, Lagas JS, Song JY et al (2016) Ritonavir inhibits intratumoral docetaxel metabolism and enhances docetaxel antitumor activity in an immunocompetent mouse breast cancer model. Int J Cancer 138:758-769. https://doi.org/10.1002/ ijc. 29812

113. Suh J, Payvandi F, Edelstein L (2002) Mechanisms of constitutive NF- $\mathrm{KB}$ activation in human prostate cancer cells. Prostate 52:183-200. https://doi.org/10.1002/pros.10082

114. Yang Y, Ikezoe T, Nishioka C et al (2006) NFV, an HIV-1 protease inhibitor, induces growth arrest, reduced Akt signalling, apoptosis and docetaxel sensitisation in NSCLC cell lines. Br J Cancer 95:1653-1662. https://doi.org/10.1038/sj.bjc.6603435

115. Wendel HG, Stanchina D, Fridman JS et al (2004) Survival signalling by Akt and eIF4E in oncogenesis and cancer therapy. Nature 428:332-337. https://doi.org/10.1038/nature02369

116. Dey G, Bharti R, Das AK et al (2017) Resensitization of Akt induced docetaxel resistance in breast cancer by 'Iturin A' a lipopeptide molecule from marine bacteria Bacillus megaterium. Sci Rep. https://doi.org/10.1038/s41598-017-17652-z

117. Vinod BS, Nair HH, Vijayakurup V et al (2015) Resveratrol chemosensitizes HER-2-overexpressing breast cancer cells to docetaxel chemoresistance by inhibiting docetaxel-mediated activation of HER-2-Akt axis. Cell Death Discov 1:15061. https://doi. org/10.1038/cddiscovery.2015.61
118. Srirangam A, Mitra R, Wang M et al (2006) Effects of HIV protease inhibitor ritonavir on Akt-regulated cell proliferation in breast cancer. Clin Cancer Res 12:1883-1896. https://doi. org/10.1158/1078-0432.CCR-05-1167

119. Kumar S, Bryant CS, Chamala S et al (2009) Ritonavir blocks AKT signaling, activates apoptosis and inhibits migration and invasion in ovarian cancer cells. Mol Cancer. https://doi. org/10.1186/1476-4598-8-26

120. de Weger VA, Stuurman FE, Hendrikx JJMA et al (2017) A doseescalation study of bi-daily once weekly oral docetaxel either as ModraDoc001 or ModraDoc006 combined with ritonavir. Eur J Cancer 86:217-225. https://doi.org/10.1016/j.ejca.2017.09.010

121. de Weger VA, Stuurman FE, Mergui-Roelvink M et al (2016) A phase I dose-escalation trial of bi-daily (BID) weekly oral docetaxel as ModraDoc006 in combination with ritonavir. Ann Oncol 27:vi130. https://doi.org/10.1093/annonc/mdw368.42

122. De Weger VA, Stuurman FE, Koolen SLW, et al (2019) A phase I dose escalation study of once weekly oral administration of docetaxel as ModraDoc001 capsule or ModraDoc006 tablet in combination with ritonavir. Clin Cancer Res. https://doi. org/10.1158/1078-0432.CCR-17-2299

123. Gills JJ, Lopiccolo J, Tsurutani J et al (2007) Nelfinavir, a lead HIV protease inhibitor, is a broad-spectrum, anticancer agent that induces endoplasmic reticulum stress, autophagy, and apoptosis in vitro and in vivo anticancer agent that induces endoplasmic reticulum stress, autophagy, and Apo. Clin Cancer Res 13:51835195. https://doi.org/10.1158/1078-0432.CCR-07-0161

124. AbbVie BV (2019) Norvir, INN-ritonavir-summary of product characteristics. https://www.ema.europa.eu/en/documents/ product-information/norvir-epar-product-information_en.pdf. Accessed 20 Apr 2019

125. Marzolini C, Gibbons S, Khoo S, Back D (2016) Cobicistat versus ritonavir boosting and differences in the drug-drug interaction profiles with co-medications. J Antimicrob Chemother 71:1755-1758. https://doi.org/10.1093/jac/dkw032

Publisher's Note Springer Nature remains neutral with regard to jurisdictional claims in published maps and institutional affiliations. 